
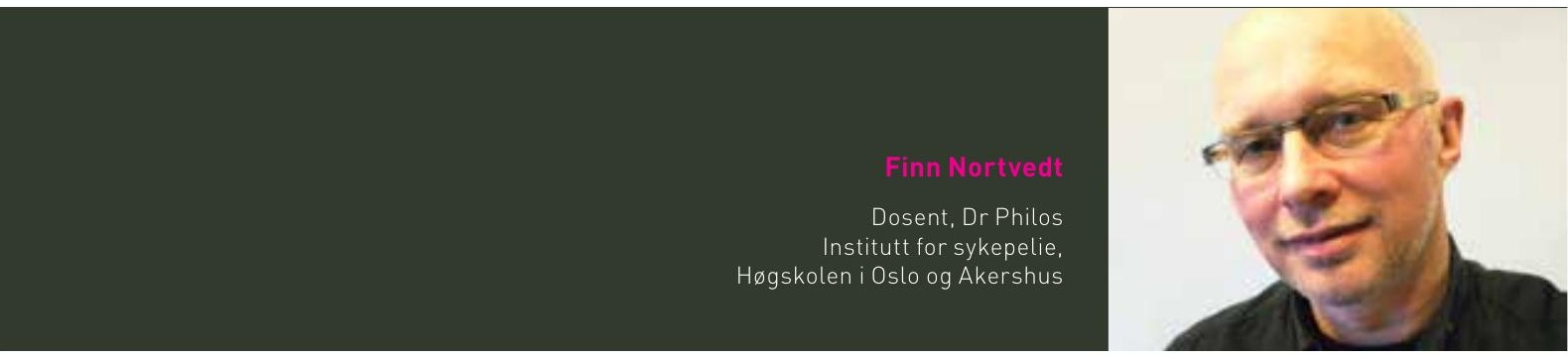

\title{
Kan smerte defineres?
}

\section{> Smerte kan vanskelig underlegges definisjonsmessige krav som tilfredsstiller normen om tilslutning til en allmenn og akseptabel forståelse.}

Spørsmålet jeg stiller i dette essayet kan synes underlig, ikke minst i lys av de definisjoner på smerte som er utviklet og som har status og konsensus både i forskningsmiljøene og blant klinikere. Grunnlaget for spørsmålet og de problemstillinger jeg vil adressere tar utgangspunkt i at smerte ikke kun er et empirisk fenomen, men også har en ontologisk side som er lite belyst. Slik jeg ser det, lar denne ontologiske dimensjonen seg vanskelig fange inn i definisjonsmessige termer.

\section{EN TRUSSEL}

Fra et ontologisk perspektiv er smerte knyttet til væren, og er uløselig forbundet med menneskets eksistens som et sårbart og utsatt individ. I tråd med den tyske eksistensfilosofen Martin Heidegger kan smerte forstås som en form for menneskelig væren (1). For Heidegger var smerte et mysterium som på den mest intime måte var forbundet med væren eller det han kaller dasein.
Fra et ontologisk utgangspunkt er smerte det som trer fram i bevisstheten som en kroppslig erfaring av å ha vondt. Smerten er ikke noe vi selv inviterer inn i våre liv; den kommer ubedt. Smerten er uunngåelig, den er ikke vår egen konstruksjon, men viser seg kroppslig og er udiskutabelt til stede. Vi er aldri i tvil om det når vi kjenner smerte. Vi vet hva det er med en gang og mobiliserer umiddelbart våre krefter for å motarbeide og fjerne den som den trusselen den utgjør i våre liv. Smerte følger oss gjennom hele livsløpet fra før fødsel til død. Den verner og varsler om skade og sykdom. Dette er smertens funksjonelle aspekt og er den akutte smertens kjennetegn. Men smerte har også en annen side; den er dysfunksjonell når den blir kronisk. Som kronisk og vedvarende er smerte en trussel mot menneskelig liv og eksistens.

Det at smerte er universelt og knyttet til vår «væren-i- verden» er et viktig kjennetegn som smerte har til felles med et annet ontologisk grunntrekk ved det å være menneske: Det at vi er dødelige. Det udiskutable faktum at dette livet en gang skal avsluttes på et tidspunkt, et sted og på en måte vi ikke kan forutse. Akkurat det er ute av våre hender og unndrar seg kontroll og beslutning, akkurat som smerte når den rammer oss som et lyn fra klar himmel, eller som når den kommer gradvis og sakte, men sikkert overtar kontrollen over våre liv.

\section{SMERTEFORSKNING}

Selv om smerte dermed er et fenomen som berører vesentlige sider ved vår eksistens, så er likevel hoveddelen av internasjonal smerteforskning ensidig biomedisinsk orientert. Utgangspunktet er empirisk. Det dreier seg om å få mer kunnskap om de molekylærbiologiske og nevrofysiologiske prosessene som oppfanger og leder nociseptive 


\section{Smerten er ikke noe vi selv inviterer inn i våre liv;} den kommer ubedt.

impulser fra skadested og til hjernen. Nocisepsjon innebærer aktivitet og transport av nevrofysiologisk informasjon via nociseptive nervebaner. Denne informasjonen kan omdannes til en bevisst smerteerfaring etter en videre fortolkning og bearbeiding i hjernen. Jeg understreker kan fordi vi vet at det ikke er noen nødvendig og absolutt årsakssammenheng mellom vevsskade, og dermed aktivering i det nociseptive systemet, og opplevelsen av smerte. Smerte kan erfares uavhengig av nocisepsjon, og nociseptiv aktivitet gir ikke nødvendigvis smerte.

Den biomedisinsk orienterte smerteforskningen har dermed sitt hovedfokus rettet mot å utvikle kunnskap om de nociseptive prosessene i nervesystemet, inkludert hva som skjer hvor i hjernen når de nociseptive impulsene når fram til og bearbeides i basale hjernestrukturer. Resultater fra MRI- og PETskanninger av hjernen peker mot at det ikke er et enkelt nettverk, men flere regioner i hjernen som er involvert i å bearbeide denne nociseptive informasjonen. Det involverer både somatosensorisk hjernebark, limbiske strukturer og prefrontal hjernebark som mottar parallell informasjon fra multiple nociseptive baner (2).

Og likevel, selv om vi vet mye om de nociseptive prosessene som utgjør en viktig betingelse for smerteopplevelse, så vet vi ikke hvordan biologisk informasjon brutt ned på molekylærnivå og elektriske impulser kan fore til bevissthet. Til det å erfare smerte som smertefullhet, til det å erfare bevisst at noe gjør vondt. Her står vi fremdeles overfor et forklaringsgap som engasjerer forskere på et bredt plan fra naturvitere til filosofer.

\section{ULIKE DEFINISJONER}

At smerte er subjektivt er en kjensgjerning og noe som det

\section{Smerte er således aldri verken psykisk eller fysisk, men alltid en totalopplevelse.}

synes å være allmenn konsensus om innenfor både forskning og klinikk. Et av de klareste utsagnene når det gjelder synet på subjektivitet og smerte er formulert av den amerikanske kreftsykepleieren Margo McCaffery. Allerede i 1968 presenterte hun en operasjonell definisjon på smerte som lyder: "Pain is whatever the experiencing person says it, existing whenever he says it does.» (3, s. 14). McCaffery framhever at dette er en operasjonell definisjon og ikke en definisjon i streng forstand. Dette begrunner hun med at smerte faktisk motsier seg å bli definert: "Pain defies definition». (3, s. 14). Hun begrunner imidlertid ikke dette standpunktet nærmere.

McCaffery vektlegger at det formidles en bestemt holdning som dreier seg om at vi må tro på pasienten når han sier at han har vondt. McCaffery presiserer også i sin utlegning av «definisjonen» at den er ment å innbefatte også de nonverbale signalene pasienten formidler når han har vondt. Både hva han sier og hva han gjør må tas med $\mathrm{i}$ betraktning og fortolkes av syke-

pleieren. Dette er en uhyre viktig presisering fordi den åpner for å innbefatte pasienter som av ulike grunner mangler evne til språklig formidling av sin smerte. Det kan være nyfødte, demente og bevisstløse pasienter.

De siste årene har det blitt utviklet en rekke smertekartleggingsverktøy som også vektlegger observasjon av smerteatferd. Det gjelder spesielt innenfor sykepleien til nyfødte så vel som i pleien av demente. En smertedefinisjon som inkorporerer dette perspektivet og som kan sees på som en nødvendig utvidelse og 


\section{Smerte har en psykologisk så vel som en fysiologisk,} kulturell og eksistensiell side.

presisering av McCafferys definisjon er lansert av Kaasalainen: «Pain is an unpleasant subjective experience that can be communicated to others through self-report when possible, or through a set of pain-related behaviors» $(5$, s. 7$)$.

\section{ALLTID SUBJEKTIV}

Den rådende definisjonen av smerte, som har allmenn tilslutning $\mathrm{i}$ forskningsmiljøene og blant regel må erkjenne at smerten har en direkte fysisk årsak.

Som vi ser av kommentaren til definisjonen, trekkes det nødvendige skillet mellom nocisepsjon og smerte som de hevder er en psykologisk tilstand. Det er imidlertid underlig at kommentaren så sterkt og ensidig vektlegger at smerte som de sier "alltid er en psykologisk tilstand.» Dermed kan det synes

\section{Smerte er en kompleks persepsjon betinget av personens eksistens i verden.}

klinikere, er IASP $>$ s definisjon fra 1994: «An unpleasant sensory and emotional experience associated with actual or potential tissue damage or described in terms of such damage».

IASP framhever i en utdypende note noen viktige presiseringer til definisjonen. Det framheves at selv om evnen til å formidle smerte via språk er borte, opphever ikke dette muligheten for at personen opplever smerte og har behov for smertelindring. Det framheves også at smerte alltid er subjektivt. Videre presiseres det at smerte ikke er et stimulus, og at aktivitet som er framkalt i nociseptorer og i nociseptive baner ikke er smerte. I tillegg hevdes det at smerte alltid er en psykologisk tilstand selv om man som som om det menes at smerte først og fremst er "psykisk» eller psykologisk, noe det ikke er grunnlag for å hevde. Smerte har en psykologisk så vel som en fysiologisk, kulturell og eksistensiell side. At disse dimensjonene varierer i sin dominans og styrke avhengig av den aktuelle kontekst og den konkrete smertens karakter, ville vært en mer korrekt påpekning. Smerte er således aldri verken psykisk eller fysisk, men alltid en totalopplevelse som involverer både eksistensielle så vel som fysiologiske og psykologiske aspekter.

\section{KOMPLEKS PERSEPSJON}

En fjerde definisjon som er presentert av Basbaum mfl. (6) ser smerte som en kompleks persep- sjon, og det presiseres at smerte ikke er et stimulus. Det eksisterer ingen «smertereseptorer» i nervesystemet eller «smertebaner» i hjernen. Det framheves at erfaringen av smerte er sluttproduktet eller resultatet av prosesser i et komplisert informasjonsledende nettverk. Det framkommer ikke hvor dette nettverket er lokalisert eller hva det består av, men det er nærliggende å anta at forfatterne her sikter til cerebrale - nettverk. Artikkelforfatterne er sentrale og anerkjente smerteforskere med basis i nevrovitenskap, anestesiologi og patofysiologi. Et annet viktig spørsmål som blir stående åpent og uavklart er hva som ligger i det at smerte betraktes som en kompleks persepsjon. Hva slags persepsjon er det snakk om? Er det å betrakte som en biologisk prosess og hvor opphavsstedet for selve persepsjonsprosessen er knyttet til hjernestrukturer? Smerte vil dermed forstås som en bevisst og perseptuell erfaring hvor nociseptiv informasjon omdannes til smerteopplevelse. Dette er også $i$ tråd med den vektlegging av nevrofysiologiske prosesser som for øvrig er dominerende i den omtalte artikkelen (6).

Men følgende spørsmål må stilles: Er disse prosessene i hjernen isolerte prosesser? $\mathrm{Og}$ 
hva er dette nettverket og hvor er forbindelsen til det kroppslige? Hjernen er jo ikke isolert fra resten av kroppen, og det er som levende kropper vi erfarer smerte! Her kan den franske fenomenologen og filosofen Maurice Merleau-Ponty (7) gi oss en annen forståelse. Han utviklet en filosofi om kroppens rolle i persepsjonen. Han påpeker at det ikke er mine øyne som ser, eller mine ører som hører, heller ikke er det min hjerne som tenker. Snarere er det slik at jeg er min kropp, og det er som kroppslig subjekt jeg ser, hører, tenker og opplever smerte (8).

Denne smerten erfares av en person som befinner seg innenfor en horisont av kultur og mening. Dette former og preger personens erfaring av verden samtidig som verden også alltid preger smerteerfaringen i en gjensidig dialektikk. Det er kroppen som gir oss tilgang til verden, og som også er grunnlaget for erkjennelse og språk. Det at mennesket er et fortolkende og kroppslig erfarende subjekt, er et viktig utgangspunkt når vi skal forstå og hjelpe personer som har smerte

\section{KONKLUSJON}

Språkforskeren Elaine Scarry har i sitt klassiske verk The body in Pain (9) studert smerte hos personer som opplever tortur og krig. Hun framhever at smerte når den er på sitt mest intense unndrar seg språklige beskrivelser, og hun hevder at: "It is the intense pain that destroys a person's self and world, a destruction experienced spatially as either the contraction of the universe down to the immediate vicinity of the body or as the body swelling to fill the entire universe» $(9$, s. 35).

Scarry forteller om en smerte som er så voldsom og altoppslukende i sin karakter at den ødelegger personen og personens forhold til verden, og dermed destruerer den også språket og evnen til språklig formidling av smerten. En smerte som unndrar seg språklig formidling kan vanskelig la seg definere hvis vi forstår en definisjon som det som i få setninger forklarer og avgrenser et betydningsinnhold i ord, uttrykk eller begrep så nøyaktig som mulig. En slik definisjon skal også, dersom den har noen hensikt, fungere slik at alle som leser eller hører ordet smerte skal få en sammenfallende oppfatning av hva smerte er og ikke er.

Smerte er som vist en kroppslig og individuell erfaring av å ha «vondt», og denne erfaringen kan ikke reduseres til å være et sluttresultat av en nevrofy- siologisk prosess. Smerte er en kompleks persepsjon betinget av personens eksistens i verden som et sansende og kroppslig subjekt, og som uttrykker seg ulikt og med stor variasjon fra individ til individ.

Min konklusjon er derfor at smerte vanskelig kan underlegges definisjonsmessige krav som tilfredsstiller normen om tilslutning til en allmenn og akseptabel forståelse, uttrykt i en setning som forklarer betydningsinnholdet til fenomenet.

\section{REFERANSER}

1. Heidegger M. The Question of Being. Oversatt av William Kluback og Jean T. Wilde. New York: Twayne Publishers. 1958

2. Apkarian AV, Bushnell MC, Treede RD et al. Human brain mechanisms of pain perception and regulation in health and disease. EUR J Pain 2005;9:463-84. 3. McCaffery, M. Nursing the patient in pain. London, New York. Harper \& Row Publishers; 1984

4. Kaasalainen, S. Pain assessment in older adults with dementia: using behavioral Observation methods in clinical practice. Geontol Nursing June 2007; 33:6-10. Review. 2007.

5. Basbaum, A. Bushnell, C. Devor, D. Pain; Basic mechanisms. I: Pain 2008, An updated review, refresher course syllabus. Seattle, USA: IASP Press, P 3-9.

7. Merleau-Ponty, M. Phenomenology of perception. Routledge \& kKegan Paul. Great Britain. 1962/2000

8. Olivier A. The problem of defining pain. Philosophy today. 2008; P 3-14.

9. Scarry, E. The body in pain. Oxford University Press. Oxford. 1985. 